\title{
Plasma dilution improves cognition and attenuates neuroinflammation in old mice
}

\author{
Melod Mehdipour • Taha Mehdipour • Colin M. Skinner • Nathan Wong • Chao Liu • \\ Chia-Chien Chen • Ok Hee Jeon • Yi Zuo • Michael J. Conboy • Irina M. Conboy
}

Received: 7 August 2020 /Accepted: 1 November 2020 / Published online: 15 November 2020

(C) The Author(s) 2020

\begin{abstract}
Our recent study has established that young blood factors are not causal, nor necessary, for the systemic rejuvenation of mammalian tissues. Instead, a procedure referred to as neutral blood exchange (NBE) that resets signaling milieu to a pro-regenerative state through dilution of old plasma, enhanced the health and repair of the muscle and liver, and promoted better hippocampal neurogenesis in 2-year-old mice (Mehdipour et al., Aging 12:8790-8819, 2020). Here we expand the rejuvenative phenotypes of NBE, focusing on the brain. Namely, our results demonstrate that old mice perform much better in novel object and novel texture (whisker discrimination) tests after a single NBE, which is accompanied by reduced neuroinflammation (less-activated $\mathrm{CD} 68^{+}$microglia). Evidence against attenuation/dilution of peripheral senescenceassociated secretory phenotype (SASP) as the main
\end{abstract}

M. Mehdipour - T. Mehdipour - C. M. Skinner - N. Wong •

C. Liu • M. J. Conboy • I. M. Conboy $(\bowtie)$

Department of Bioengineering and QB3, UC Berkeley, Berkeley, CA, USA

e-mail: iconboy@berkeley.edu

C.-C. Chen - Y. Zuo

Department of Molecular and Cellular Biology and QB3, UCSC, Santa Cruz, CA, USA

O. H. Jeon

Buck Institute for Research on Aging, 8001 Redwood Boulevard, Novato, CA, USA

\section{O. H. Jeon}

Department of Biomedical Sciences, Korea University College of Medicine, Seoul, Republic of Korea mechanism behind NBE was that the senolytic ABT 263 had limited effects on neuroinflammation and did not enhance hippocampal neurogenesis in the old mice. Interestingly, peripherally acting ABT 263 and NBE both diminished SA- $\beta$ Gal signal in the old brain, demonstrating that peripheral senescence propagates to the brain, but NBE was more robustly rejuvenative than ABT 263, suggesting that rejuvenation was not simply by reducing senescence. Explaining the mechanism of the positive effects of NBE on the brain, our comparative proteomics analysis demonstrated that dilution of old blood plasma yields an increase in the determinants of brain maintenance and repair in mice and in people. These findings confirm the paradigm of rejuvenation through dilution of age-elevated systemic factors and extrapolate it to brain health and function.

Keywords Plasma dilution - Neuroinflammation · Neutral blood exchange $\cdot$ Senolytics $\cdot$ Memory and Cognition $\cdot$ Rejuvenation

\section{Introduction}

Heterochronic parabiosis is a procedure where a young animal and an old animal are surgically conjoined so that the two partners share a common circulatory system after a certain amount of time [1-3]. Parabiosis studies have yielded a plethora of insights regarding mechanisms that underlie the aging of stem cell niches. It was shown that old partners have better health in multiple tissues when they shared blood with a younger 
animal $[1,4,5]$. A prominent interpretation of heterochronic parabiosis is that aging is malleable and that the aging process can be slowed or even reversed [1, 6]. With this, heterochronic parabiosis studies seeded the field of systemic aging and rejuvenation.

Brain aging in particular is associated with a progressive loss of functionality and is thought to be in large part the result of an excessive activation of microglia, the brain-resident myeloid cells [7]. The age-related declines in brain function and cognition (among many other functions in the body) were once considered inevitable and permanent [8]. Parabiosis studies, interestingly, have challenged this notion by illustrating the plasticity of brain maintenance and function after changing the age of the blood and also providing the environmental enrichment and shared young organs to the old partners $[5,9,10]$.

Several systemic proteins and young plasma infusions were suggested to influence the plasticity of brain aging [9, 11-17], albeit with some controversy to the actual age-specific levels of some of these candidate factors, such as GDF11, B2M, CCL11, and TIMP2 [9, 18-24]. There was also a lack of health span increase in young plasma infusion studies [25]; and while safety trials were successful, the young blood approaches have not been demonstrated to be effective in improving the health of the brain or any other tissue in clinic [26]. In concert, heterochronic blood transfusion exchange experiments have shown that in the absence of the organ sharing and environmental enrichment of parabiosis, young blood does not rejuvenate the old brain [21].

As we investigate and form an evolutionary conserved paradigm of systemic rejuvenation, our data demonstrated that young blood is not the primary determinant, and instead, dilution of old blood plasma yields a robust resetting of the systemic signaling milieu to youth and health, rejuvenating multiple tissues [18]. The study of the brain in that report was limited to hippocampal neurogenesis; here we expand the work to other important facets of brain health: neuroinflammation and cognition. Our data demonstrate that neuroinflammation (specifically the activation of microglia), declines and the cognitive capacity of old mice (novel object and novel texture tests), improves after a single NBE. In correlation with the phenotypes of rejuvenated brain health and function, our comparative proteomics analysis revealed specific neuroprotective, neurogenic, and neuroactivity regulating proteins that become systemically upregulated in mice and people after plasma dilution. Considering that therapeutic plasma exchange (TPE) is FDA approved, this study suggests a use of this procedure to prevent, attenuate, and possibly even reverse the degenerative and inflammatory diseases of the brain.

\section{Results}

Cognitive capacity of old mice is improved through a single NBE procedure

Young (2-4 months) and old (22-24 months) male C57/ B6 mice underwent one NBE procedure, as published [18]. Isochronic exchanges between young mice (young exchanged with young, YY) and old mice (old exchanged with old, OO) were performed, as controls for the procedure. Six days after the single NBE, or control YY or OO blood exchange, brain neuroinflammation assays, cognitive performance tests, and blood proteomics assays were performed, as in [21, 27-29] (Fig. 1a, b).

Cognitive changes occur naturally during the process of mammalian aging, typically associating with a decline in learning and memory [30]. Aged mammals exhibit poor cognitive capacity to detect and interact with novel textures and novel objects, as compared to much better inquisitiveness in such settings by young mammals $[9,10,15,29,31,32]$. This aspect of cognition, which also reflects the quality of short-term memory, can be examined in the whisker discrimination (WD) task that tests sensory processing through the barrel cortex and memory through the hippocampus $[32,33]$ and by administering the novel object recognition (NOR) test [28], where sensory and memory information is processed through both the hippocampus and the perirhinal regions [34]. Aged mice typically have deficiency in short-term memory that compounds their inability to distinguish between different textures and different objects [29].

Whisker discrimination (Fig. 1c) and novel object recognition (Fig. 1d) tests were performed after an NBE to old mice, as in [29], using OO isochronically exchanged mice as controls for the procedure and YY isochronically exchanged mice, as standards for healthy young cognitive capacity. As expected, OO mice had a profound age-specific decline in their NOR and WD test 
a

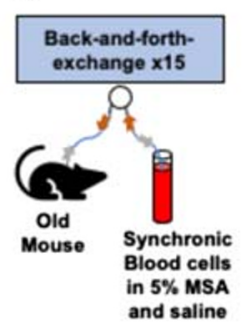

C
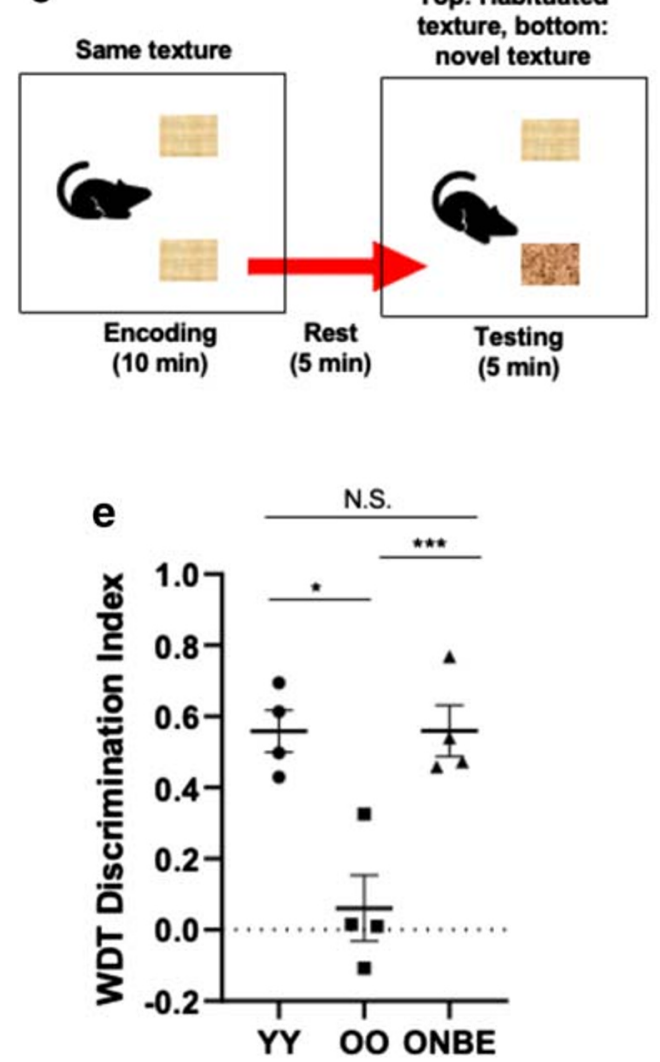

Fig. 1 NBE quickly and robustly improves the cognitive performance of old mice. a Experimental schematic. Catheters were installed into the jugular veins of young or old mice, which had $50 \%$ of theirblood plasma exchanged with normal saline ( $0.9 \%$ sodium chloride), $5 \%$ mouse serum albumin (MSA), and synchronic blood cells, as previously published [21]. b Timeline. At day 1, mice were habituated for whisker discrimination (WD) and novel object recognition (NOR) behavioral tests. These mice underwent jugular vein cannulation on day 0 and blood exchange at day 1 . WD and NOR assays were performed on day 6 . Blood samples and brain were collected for tissue analysis. c Schematics of mice performing the whisker discrimination task and $\mathbf{d}$ novel object recognition assays. eOO mice performed poorly when compared

performance, as compared to YY animals (Fig. 1e, f). However, a single dilution of old plasma resulted in
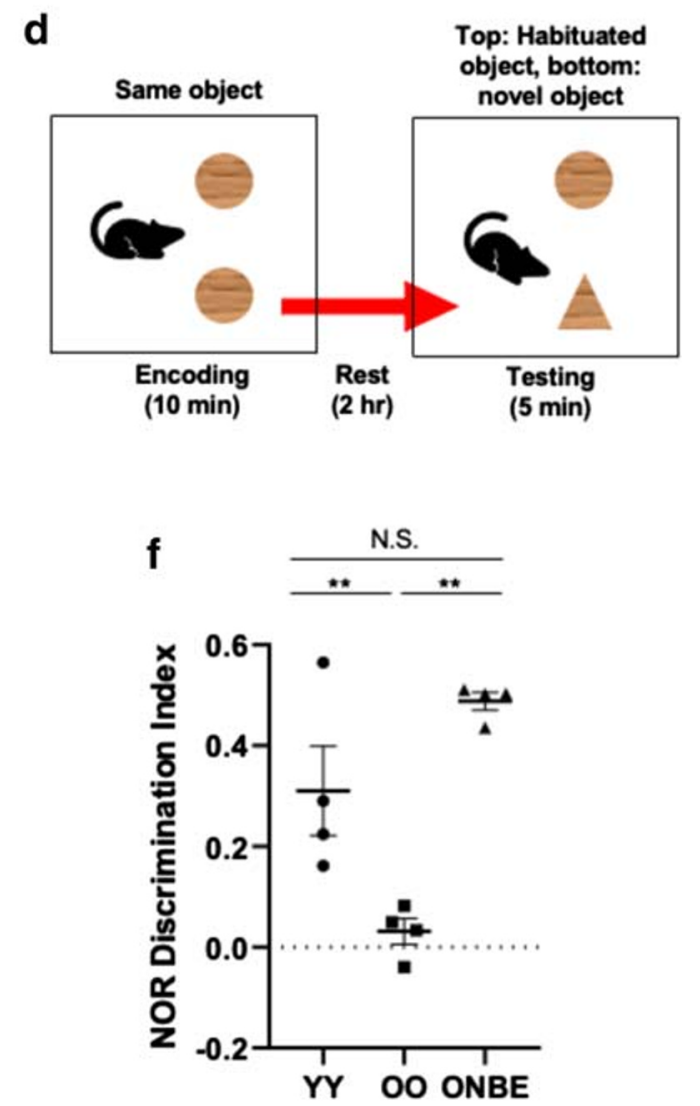

to $\mathrm{YY}$ mice, as expected $(* p$ value $=0.024)$. ONBE mice were much better at discriminating between habituated and novel textures versus $\mathrm{OO}$ animals ( $* * * p$ value $<0.00001$ ). Interestingly, ONBE mice were able to discriminate between novel and habituated textures as effectively as YY mice (N.S. $p$ value $=0.01$ ). $\mathbf{f}$ Similar trends were observed with novel object recognition studies. YY versus ONBEN.S. $p$ value $=0.99$, $\mathrm{YY}$ versus $\mathrm{OO} * * p$ value $<0.004, \mathrm{OO}$ versus $\mathrm{ONBE} * * p$ value $<0.006$. $p$ values were obtained by one-tailed Student's $t$ test, e.g., as typical for evaluating the extent of the differences in the means from three independent treatment groups, rather than comparing each group to another. $N$ of $\mathrm{YY}=4, N$ of $\mathrm{OO}=4$, and $N$ of $\mathrm{ONBE}=4$ for each behavioral assay

much improved cognitive performance of old mice, which became, in fact, similar to that of the YY cohort 
(Fig. 1e and f). The encoding phase for each of these behavioral studies is shown in Supplementary Figure 1.

These results establish that functionality of the old brain (short memory and inquisitiveness) is robustly and rapidly improved by the dilution of old blood plasma.

Age-associated increase in neuroinflammation is significantly attenuated by NBE

Neuroinflammation increases with age in mice and humans, which contributes to the decline in cognitive capacity of old mammals $[9,15,29]$. Thus, we studied if cognitive improvements in the old mice after NBE correlated with the diminished neuroinflammation.

To this end, we performed immunofluorescence on CD68, the marker of activated microglia, in $25-\mu \mathrm{m}$ serial brain cryosections of young and old mice at 6 days post NBE or OO isochronic exchange, as well as the positive control for low neuroinflammation, YY exchanged mice.

Figure 2a illustrates an anatomical map depicting various structures in coronal mouse brain sections (adapted from the Allen Brain Atlas) that were examined for the presence of $\mathrm{CD}^{+} 8^{+}$cells. Sections were collected from the plane of maximally exposed dentate gyrus (DG) of the hippocampus. Activated CD68 ${ }^{+}$ (high) microglial cells were found just beneath (ventral) to the DG part of the brain, in the thalamus, midbrain, and zona incerta of the thalamus in the $\mathrm{OO}$ brains. These areas of the sections were imaged; and other parts of the OO brains were profiled, as well, but did not have detectable $\mathrm{CD} 68^{+}$microglial cells. YY and ONBE brain sections were identically studied, e.g., throughout the brain in serial $25-\mu \mathrm{m}$ cryosections.

As shown in Fig. $2 \mathrm{~b}$ and quantified in $\mathrm{C}, \mathrm{CD} 68^{+}$cells were numerous in the old control brains (OO) and minimal/non-existent in young control brains (YY), which is consistent with the previously published age increase of $\mathrm{CD}^{+} 8^{+}$brain-resident cells $[10,17,29]$. Importantly, neuroinflammation became significantly diminished in old mice after one NBE. The representative and quantified images are of the areas that are depicted in Fig. 2a; profiling the entire YY and ONBE brains by immunofluorescence microscopy did not reveal $\mathrm{CD} 8^{+}$cells at other locations, either. The nonspecific immunofluorescence of isotype-matched $\mathrm{IgG}$ controls was negligible (Fig. 2b).

These results demonstrate that neuroinflammation becomes significantly and quickly diminished in the brains of old mice after a single large volume dilution of blood plasma by NBE.

ABT 263 senolytic and NBE both reduce brain senescence, but ABT 263 fails to enhance neurogenesis or robustly reduce neuroinflammation in the old mice

To examine whether and to what degree the positive effects of NBE might be emulated by ablation of senescent cells, we performed studies with ABT 263.

ABT 263 (Navitoclax) is a chemotherapy drug that is used to induce apoptosis in cervical, esophageal, leukemia, and lung cancer cells by inhibiting the antiapoptotic proteins, Bcl-2 and Bcl-xL [35-38]. ABT 263 was shown to selectively clear senescent cells in vivo through inhibition of $\mathrm{Bcl}$ proteins [39-41] and to diminish SASP [42].

ABT drugs have been tested on patient glioblastomas in culture [43]; but these molecules are generally considered to be too large to cross the blood-brain barrier (BBB) [44]. Yet, the BBB becomes more porous with age even to such large proteins as albumin [45-47]. Additionally, peripheral inflammation has been reported to influence central inflammation and brain health [48-50]. Peripheral systemic senescence-associated secretory phenotype (SASP) proteins traverse the aged BBB and cause neuroinflammation and immune infiltration $[45,46,51,52]$.

We therefore hypothesized that peripheral senescent cell clearance by ABT 263 might diminish the levels of SASP systemically, preventing their mobilization to the brain, thereby improving hippocampal neurogenesis and attenuating neuroinflammation in old mice. And we were interested to determine whether a dilution of systemic SASP by NBE might attenuate the load of senescent cells in the old brain.

To test these hypotheses, we compared the effects of ABT 263 and NBE, using the SA- $\beta$ Gal assay on brain sections. ABT 263 or vehicle control was administered to old C57/B6 mice (22-24 months of age) by gavage for two 7-day cycles with a 2-week time interval between each cycle at $50 \mathrm{mg}$ per $\mathrm{kg}$ of body weight per day. NBE and control isochronic OO exchanges were performed, as described above. Freshly frozen $25-\mu \mathrm{m}$ brain sections were assayed by senescence-associated $\beta$-galactosidase (SA- $\beta$-gal) staining, which revealed that both ABT 263 and NBE significantly reduced the load of senescent cells in the old brains, as compared to 
a
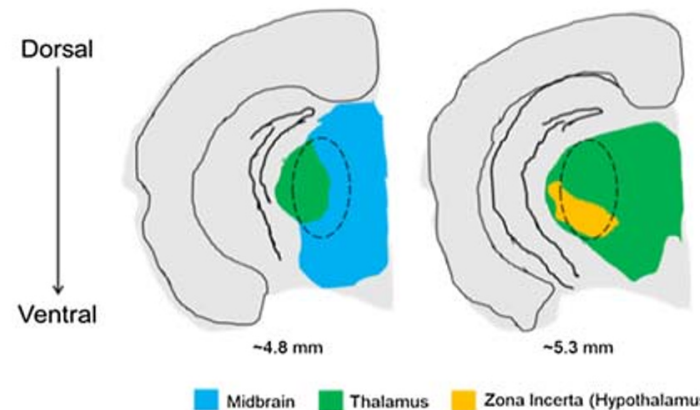

$-5.3 \mathrm{~mm}$

Zona Incerta (Hypothalamus)

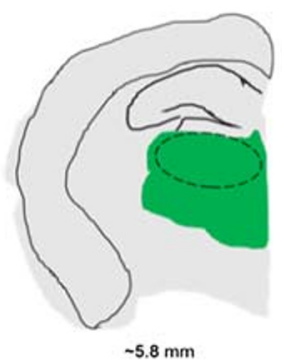

$-5.8 \mathrm{~mm}$ b

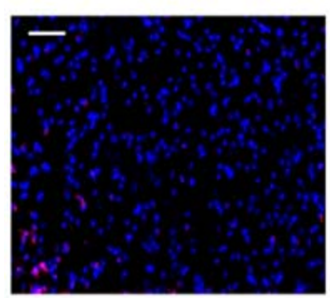

YY

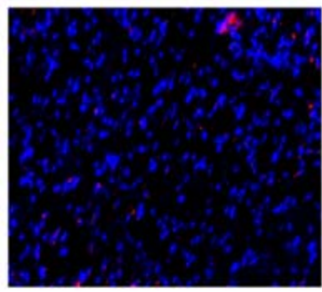

ONBE
CD68/Hoechst

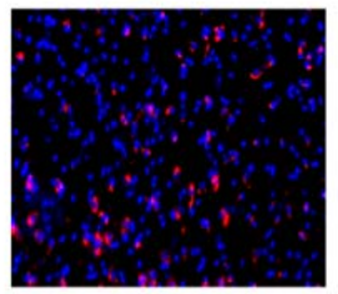

००

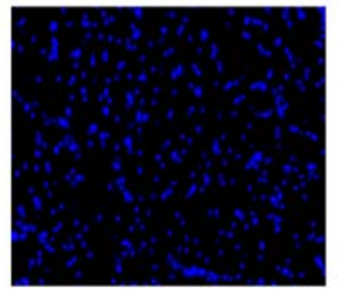

IgG
Fig. 2 Neuroinflammation is reduced by a single NBE in old mice. a Schematic of serial sections of $25 \mu \mathrm{m}$ (denoted by the dashed ovals) that were taken from regions ventral to the dentate gyrus, e.g., where an apparent age-associated increase in relative number of $\mathrm{CD}^{+} 8^{+}$cells was detected (green: thalamus, blue: midbrain, and orange: zona incerta of the thalamus). b Immunofluorescence was performed to assay for CD68-positive (red) activated microglia in the thalamus/hypothalamus/midbrain regions of brains from mice of each cohort. Representative CD68/ Hoechst double-positive cells in the specified areas are shown for

the vehicle control for ABT 263 and OO control exchanges for NBE (Fig. 3a, b).

Thus, interestingly, peripherally acting senolytic and dilution of old systemic milieu both reduce brain senescence.

Previous studies have shown that muscle injury by cardiotoxin (CTX) injections worsens hippocampal neurogenesis in mice $[21,29]$. To interrogate these effects in the context of ABT 263 administration, some
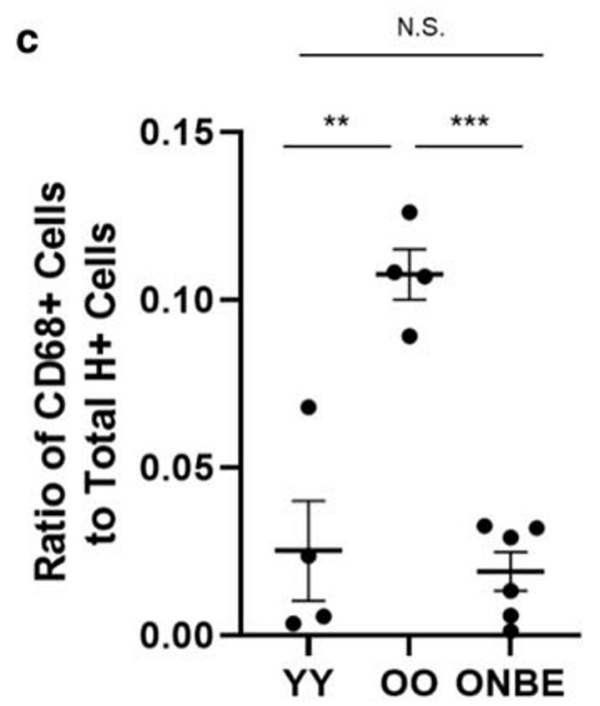

YY, OO (isochronic controls), and ONBE mice. Isotype-matched IgG negative controls show the absence of non-specific fluorescence. Scale bar $50 \mu \mathrm{m}$. c Quantification of the relative frequency of $\mathrm{CD}^{+} 8^{+} /$Hoechst $^{+}$activated microglia in the thalamus. Neuroinflammation is substantially reduced in ONBE mice when compared to that in $\mathrm{OO}$ mice $(* * * p$ value $<0.00002)$. The relative numbers of activated microglia are not significantly different between YY mice and ONBE mice (N.S. $p$ value $=0.27$ ). ** $p$ value $\mathrm{YY}$ versus $\mathrm{OO}<0.003$. $p$ values were obtained by twotailed Student's $t$ test. $N$ of $\mathrm{YY}=4, N$ of $\mathrm{OO}=4, N$ of $\mathrm{ONBE}=7$

mice received CTX injury on day 30 of the treatment, while others have not (Fig. 4a). Neurogenesis and neuroinflammation were examined in the brains of these animals as published [18, 21, 29] and shown in Fig. 2.

Neurogenesis occurs in the subgranular zone (SGZ) of the DG declines with age and is shown to be influenced by systemic factors $[5,9,10,18,21,29]$. Proliferation of neural precursor cells (NPCs) that are born in the SGZ of the DG was assayed by immunofluorescence 
of the proliferation marker Ki67 in serial brain sections (Fig. 4b). Neurogenesis was quantified throughout the thickness of each hippocampus (Fig. 4c). Consistent with the poor hippocampal neurogenesis that is typical old mice, the animals in the control group had $\sim 150$ 200 NPCs per DG $[18,21,29]$. Interestingly, the number of proliferating NPCs in hippocampi of the aged mice which were treated with ABT 263 was not significantly different from that of the vehicle controls. The numbers of proliferating NPCs in the SGZ of ABT 263or vehicle control-treated old mice were similar to those of $\mathrm{OO}$ cohort, and all were significantly lower than those of the ONBE group (Supplementary Figure 2A).

The extent of neuroinflammation was evaluated using CD68 as a marker for activated microglia (as in Fig. 2a). The relative frequency of $\mathrm{CD} 8^{+}$cells in $\mathrm{ABT}$ 263-treated aged mice remained as high as in the control group (Fig. 4d, e). The frequency of $\mathrm{CD}^{+} 8^{+}$cells was similar between ABT 263 and control vehicle cohorts and the $\mathrm{OO}$ cohort, and all were significantly higher when compared to $\mathrm{CD}^{+} 8^{+}$cell frequency in the ONBE cohort (Supplementary Figure 2B).

When performing these studies, we noticed that the magnitude of CD68 fluorescence appeared to be lower in ABT 263 cohort than in the control vehicle group (even though the numbers of the $\mathrm{CD}^{+} 8^{+}$cells did not change). Data quantification of CD68 clusters' size per cell confirmed this observation and demonstrated a significant decline in the size of CD68 clusters upon the treatment of old mice with ABT 263 (Fig. 4f).

These results demonstrate that as compared to NBE, senolytic ABT 263 does not enhance hippocampal neurogenesis and has a weaker, but measurable effect on attenuation of neuroinflammation. These differences manifest even though both ABT 263 and NBE reduce brain senescence and systemically attenuate SASP.

Evolutionarily conserved effects of NBE and TPE on systemic proteins with direct influence on the brain

Considering the uncovered multiple positive effects of NBE on brain health and function and the postulated rejuvenative effects of TPE, we performed comparative proteomics analyses on blood serum (mouse and human) that were isolated before versus after these procedures ( 6 days after NBE and 1 month after TPE). As mentioned above, the BBB becomes permeable to a number of systemic proteins with age (including TGFbeta ligands and albumin [45-47]), suggesting an increased capacity of peripheral proteins to act in the old brain.

Starting with proteomics on systemic factors that were modulated by NBE or TPE and showed $>2$-fold change with $p<0.05$, we focused on the comparative levels of the proteins that directly regulate brain health, including receptors that are present on neurons, microglia, or other brain resident cells; ligands that influence proliferation and/or differentiation of neural cells; and signaling proteins that affect neuroplasticity or are neuroprotective.

These studies identified 15 proteins that are directly significant for brain health, maintenance, and repair and that are changed in the TPE proteome, and 11 such proteins changed in the mouse NBE proteome. Interestingly in both species, dilution of old plasma ultimately resulted in a lasting elevation (not decline) of these determinants, which is consistent with our general conclusion on a resetting of the molecular signaling milieu to health (Fig. 5).

Interestingly, proteins that influence multiple parameters of brain health were simultaneously modulated by the NBE and TPE, therefore providing a mechanism for improving multiple brain health aspects at once: enhancing brain function and synaptic plasticity, improving neuroprotection, attenuating neuroinflammation, diminishing neurotoxicity, and enhancing proliferation and differentiation of neural stem cells (Table 1).

These results confirm and extrapolate the positive effects of old plasma dilution on the brain by demonstrating a lasting recalibration of systemically present molecular determinants that have direct effects on brain health and function.

\section{Discussion}

Plasma exchange is currently FDA approved for other diseases, and based on our recently published and current work, TPE yields great therapeutic potential toward treating age-associated degenerative and inflammatory diseases of the brain, as well as general age-imposed decline in brain health and function.

The use of TPE, where the patient's plasma is filtered and replaced with a 5-20\% albumin solution, was investigated for its effectiveness to mitigate the progression of mild-to-moderate Alzheimer's disease. A phase I study that began in 2005 and concluded in 2009 revealed that cognition scores and cerebrospinal fluid 
Fig. 3 ABT 263 and NBE both reduce brain senescence. Freshly frozen 25- $\mu \mathrm{m}$ cryosections of old brains were assayed by SA- $\beta$ Gal, as per manufacturer's instructions (9860S, Cell Signaling Technology). a Representative images of SA- $\beta$-gal staining, scale bar $=$ $50 \mu \mathrm{m}$. b Percent SA- $\beta$-galpositive areas per section were quantified and compared between the cohorts. Senescence of the old brain was diminished by both ABT 263 (ABT) and NBE, as compared to the vehicle control $(\mathrm{OV})$ and isochronic old-to-old blood exchanges (OO). $p$ values were obtained by two-tailed Student's $t$ test. ABT 263 versus vehicle $p=0.0001$, NBE versus OO $p=0.0002 . N=4$ animals of each cohort. Color coding illustrates the distribution of SA- $\beta$ Galpositive cells in serial brain sections of each examined animal where the same color represents serial sections of the same brain (circles, vehicle or OO; triangles, ABT 263 or NBE)
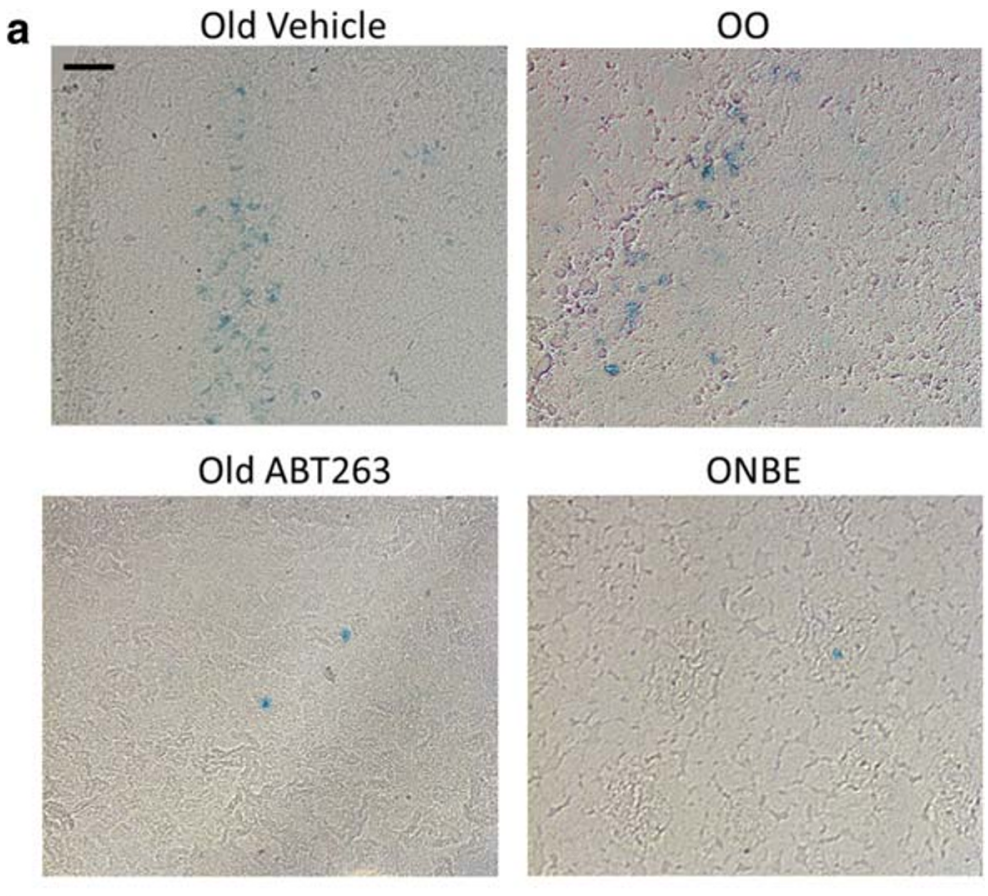

b

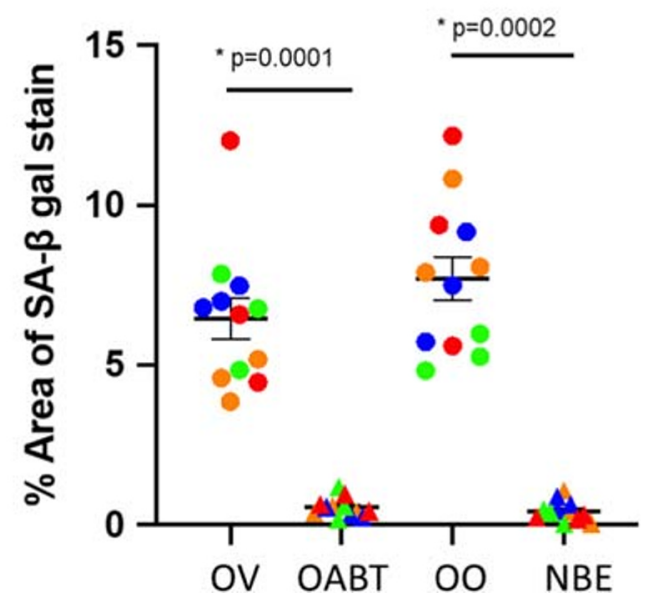

A $\beta$ changed little, yet hippocampal volume and frontal and temporal cortex perfusion increased in a 6-month follow-up [82, 83].

A phase II study beginning in 2007 and concluding in 2017 consisted of a larger patient population, measured the same parameters as phase I, and involved a more intensive plasma exchange regimen. Results from phase II were remarkable in attenuation of cognitive decline, with either close to or at $95 \%$ confidence interval. Additionally, stabilization of perfusion in the frontal, temporal, and parietal areas was observed in plasma exchange patients [83-85]. However, behavioral, functional, and cognitive improvements were not determined with statistical significance [86]. Current multicenter trials are being conducted to further investigate the efficacy of TPE in treating Alzheimer's disease [83, 86].

Our results agree with the promising direction of TPE being applied to treating Alzheimer's disease; moreover, our work expands the rejuvenative phenotypes, suggesting that brain diseases, as a class, and even physiological brain aging can be at some point prevented, attenuated, and restored to health-youth through an appropriate dilution of old blood plasma or factors.

Furthermore, we outline systemic candidate proteins that might be responsible for the positive effects of TPE/ 


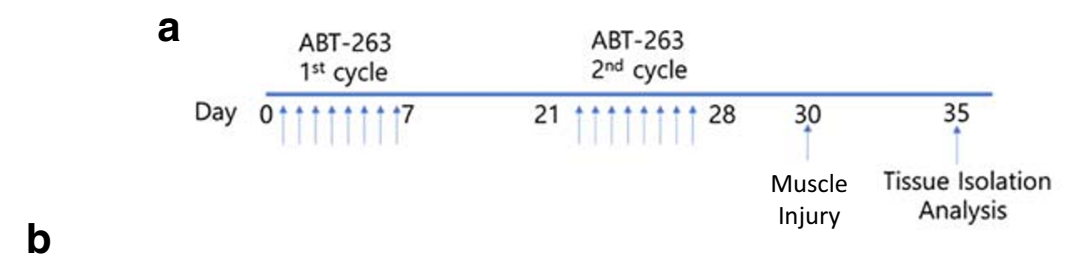

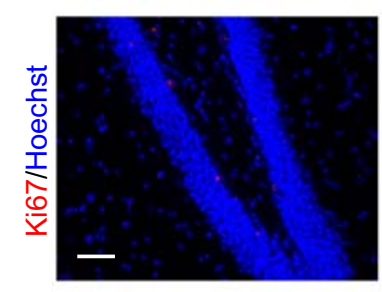

Old+Vehicle Uninjured

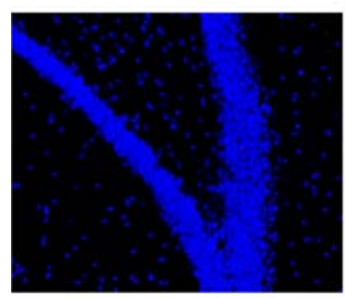

Rabbit IgG

d

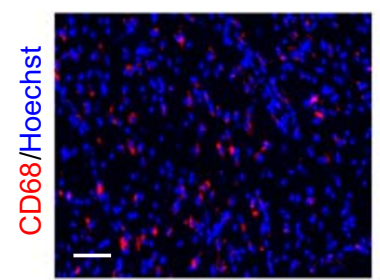

Old+Vehicle Uninjured

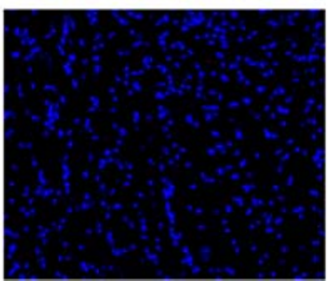

Rabbit IgG

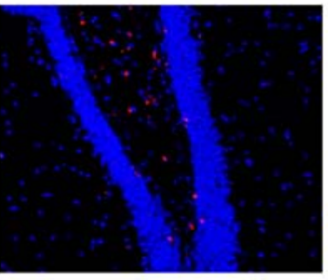

Old+Abt Uninjured

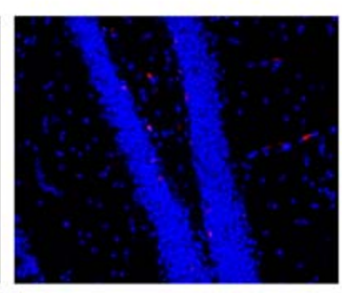

Old+Vehicle Injured

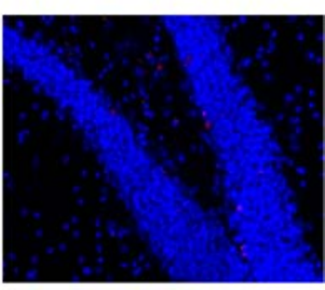

Old+Abt Injured

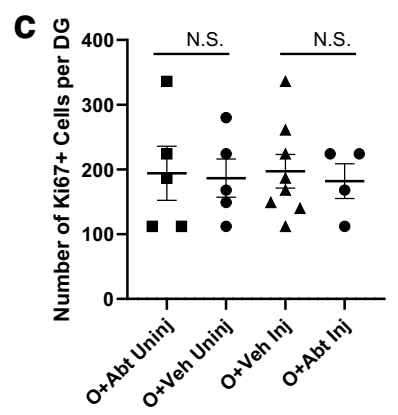

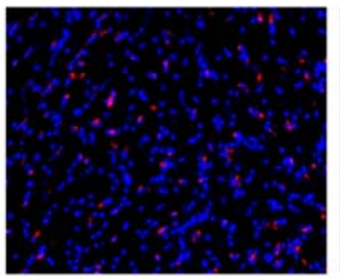

Old+Abt Uninjured

e

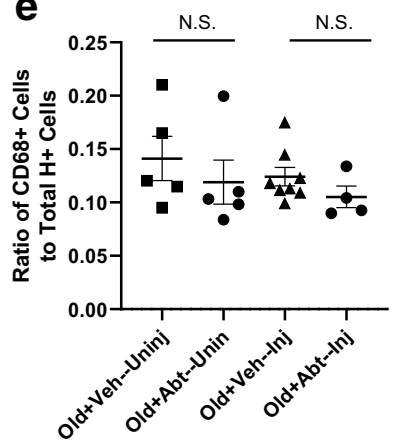

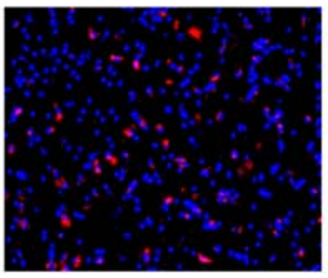

Old+Vehicle Injured

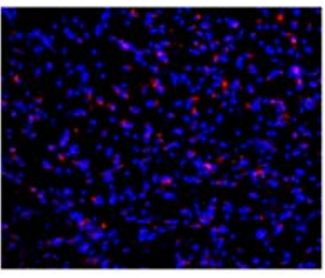

Old+Abt Injured

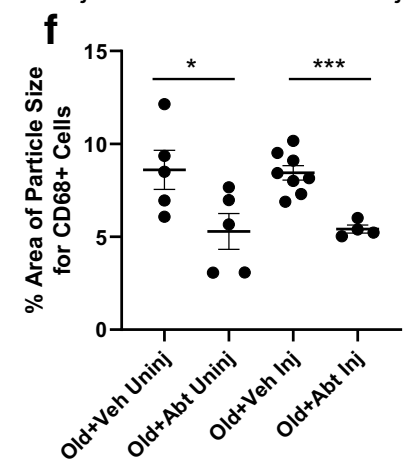

NBE on the brain, thereby suggesting future therapeutic avenues for agonist/antagonist approaches to improve brain health and reduce brain aging.
In this regard, previous studies have shown that attenuation of TGF-beta signaling by Alk5 inhibitor, particularly, when combined with ectopic oxytocin, 
Fig. 4 Effects of ABT 263 senolytic on hippocampal neurogenesis and neuroinflammation of old mice. a Schematic of the study. There were two 7-day periods where mice were given ABT 263 or vehicle by gavage once per day. A 2-week interval followed between each 7-day gavage period. TA muscles of some mice were injected with cardiotoxin for experimental injury, while other animals were not injured. b Brains were snap frozen and serially cryosectioned at $25 \mu \mathrm{m}$. These sections were immunoassayed with anti-Ki67 antibodies (proliferation marker), while using Hoechst to counterstain all the nuclei. Representative images of the hippocampal dentate gyrus show Ki67 (red)/Hoechst (blue) double-positive cells in subgranular zone (proliferating SGZ NPCs). c Quantification of Ki- $67^{+} / \mathrm{Hoechst}^{+} \mathrm{SGZ}$ cells in the dentate gyrus was performed for both injured and uninjured cohorts. ABT 263 did not improve hippocampal neurogenesis in either cohort. Old + Veh Uninj versus $\mathrm{O}+$ Abt Uninj $p$ value $=$ 0.89 ; Old + Veh Inj versus $\mathrm{O}+$ Abt Inj $p$ value $=0.72$. $p$ values were obtained by two-tailed Student's $t$ test. $N$ of Old + Veh Uninj $=5, N$ of Old + Abt Uninj $=5, N$ of Old + Veh Inj $=8, N$ of Old + Abt Inj = 4. d Immunofluorescence was performed for CD68 (activated microglia marker). Representative images of CD68 (red)/Hoechst (blue) double-positive cells. e Quantification of $\mathrm{CD} 8^{+} /$Hoechst $^{+}$cell frequency in the brain was performed for the injured and uninjured cohorts. ABT 263 did attenuate $\mathrm{CD} 68^{+}$ cell frequency. Old + Veh Uninj versus $\mathrm{O}+\mathrm{Abt}$ Uninj $p$ value $=$ 0.47 ; Old + Veh Inj versus $\mathrm{O}+\mathrm{Abt}$ Inj $p$ value $=0.21$. N.S. nonsignificant. f CD68 cluster size per cell analysis was performed on Fiji. The size of CD68 clusters was significantly reduced by ABT 263. Old + Veh Uninj versus $\mathrm{O}+$ Abt Uninj $p$ value $=0.05$; Old + Veh Inj versus $\mathrm{O}+\mathrm{Abt}$ Inj $p$ value $<0.0005$. $p$ values were obtained by two-tailed Student's $t$ test. For all experiments: $N$ of Old + Veh Uninj $=5, N$ of Old + Abt Uninj $=5, N$ of Old + Veh Inj $=8, N$ of Old + Abt Inj $=4$. Scale bar $=50 \mu \mathrm{m}$. There was no non-specific fluorescence in isotype-matched IgG negative controls

improves hippocampal neurogenesis, diminishes neuroinflammation. and improves cognition in aged mice [13, 29]. Effects of NBE are overall stronger than those of Alk5 inhibitor plus oxytocin, which is expected, as old plasma dilution acts by multiple mechanisms and elevates the levels of numerous "youthful" systemic factors [18].

Comparing NBE with another prominent pharmacological rejuvenation modality, senolytics (ABT 263 (Navitoclax) which induce apoptosis in senescent cells [87]) revealed that plasma dilution has much stronger positive effects on the old brain than ablation of senescent cells.

There is substantial interest in developing senolytic therapies to treat diseases that are associated with age. ABT 263 is of great clinical interest since it was initially used to treat various forms of cancer [88-91] and has effect on most peripheral tissues, but must be primed with additional drugs in order to affect brain tumors $[92,93]$.

The fact that NBE has a stronger effect than ABT 263 in brain rejuvenation suggests that resetting signaling milieu to health-youth by old plasma dilution is more robust for brain rejuvenation than attenuation of SASP through ablation of senescent cells. Interestingly, our data demonstrates that brain senescence is diminished by both peripherally acting ABT 263 and NBE, in support of the notion that age-elevated systemic senescence and SASP might induce central senescence [45, $46,51,52]$. The CD68 cluster size reduction, observed in this work, might be associated with a modest attenuation of neuroinflammation [94] by ABT 263. And, one of the proposed mechanisms for the amelioration of Alzheimer's disease indeed involves a reduction in neuroinflammation where peripheral modulation impacts the central brain inflammation [83]. It would be interesting to examine if ABT 263 might be effective in such applications.

Recent studies show that experimental brain injuries in mice negatively affect hippocampal health (loss of synapses, neuronal death) and impact cognition even when the foci of such injuries and subsequent microglia activation are elsewhere in the brain [95-98]. Moreover, local microglia activation leads to broad inflammatory responses in the brain through autocrine and paracrine functions of the pro-inflammatory secretome, which cumulatively increases neuroinflammation throughout the brain $[99,100]$. In concert with our findings, an injury sustained in the thalamus (e.g., one of the regions where we found an age-associated, NBE reduced neuroinflammation) activates microglia and perpetuates neurodegeneration and cognitive decline [101]. Together, these findings suggest that microglia activation is diffuse, spreading from one brain region to others.

Our study has mapped age-elevated frequencies of $\mathrm{CD} 8^{+}$cells to the thalamus, the hypothalamus, and the midbrain. Age-associated microglia activation in each of these regions is indeed causal in brain pathologies and is expected to affect brain function and cognitive performance [102-105]. And in general, neuroinflammation is, at least in part, responsible for the age-related loss of neurons [106].

Therefore, the rapid cognitive improvements of old mice in this study are thought to arise from abrogating (through NBE) the otherwise age-increased extent of neuroinflammation. Of note, plasma dilution might be also clinically relevant to the attenuation of hyper- 

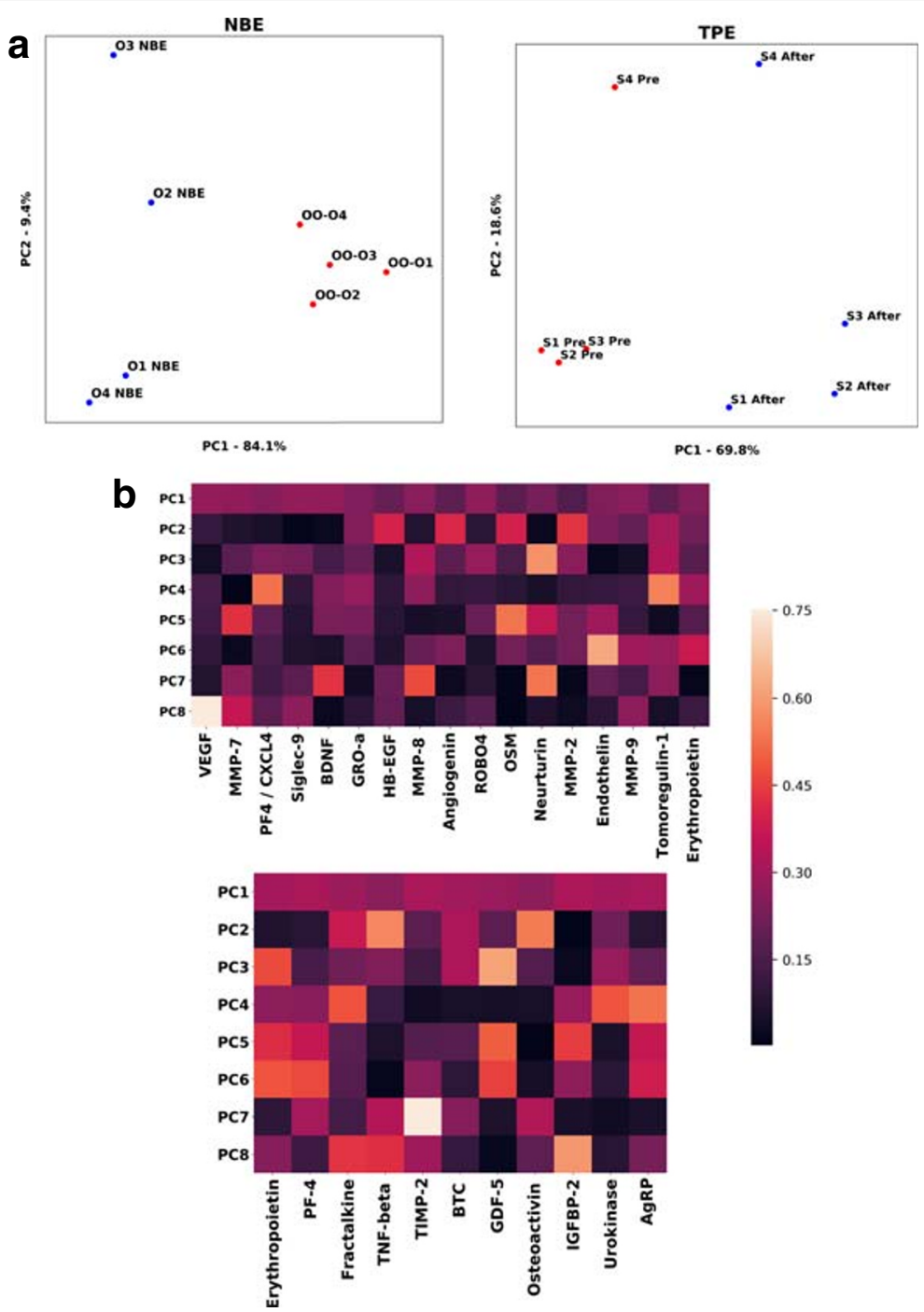

Fig. 5 Multiple determinants of brain health and function become simultaneously elevated after NBE and TPE. a PCA was performed on an aggregate dataset of serum proteomics of control old mice (old exchanged with old) and old animals that underwent one round of NBE (serum was collected 6 days after NBE), with each point representing a unique mouse whose value is computed by a PCA transformation, using as features eleven proteins that play a direct effect in brain health. In this PCA visualization, the aggregation of $\mathrm{OO}$ proteome is separated from the aggregation of ONBE proteome. The first two principle components account for

activated $\mathrm{CD} 68^{+}$microglia in psychiatric diseases, where neuroinflammation is implicated in pathology [107].

It is highly unlikely that increased neurogenesis in aged mice by NBE [18] contributes to the observed here improvement in cognition. As was the case previously
93.5\% of the variation between cohorts. B. PCA was performed on human serum proteomics, comparing Pre TPE samples with those collected at 1 month after a single procedure, using as features 17 brain health determinants. The first two principle components account for $88.4 \%$ of the variation before and after treatment. C. Heat maps for the loading scores for each principle component for the 17 determinants in human (top) and the 11 determinants in mice (bottom). Erythropoietin and PF4 were evolutionarily conserved proteins influenced by NBE and TPE. All serum samples were the same as in [18].

[29], we assayed cognitive performance 1 week after a single procedure of NBE; thus, there was not enough time for the new neurons to be formed and/or integrate into the networks.

Summarily, this work supports the paradigm that diluting and resetting to health and youth systemic 
Table 1 Proteins simultaneously modulated by the NBE and TPE

\begin{tabular}{|c|c|}
\hline & Effects on the brain \\
\hline \multicolumn{2}{|l|}{ TPE elevated } \\
\hline BDNF & Neurogenesis, neuroprotection, plasticity related to learning and memory [53] \\
\hline Tomoregulin 1 & Neuroprotection: binds amyloid- $\beta$ (A $\beta$ ) [54] \\
\hline VEGF & Neuroprotection, secreted by neurons [55] \\
\hline MMP-2, 7, 8, 9 & Synaptic re-organization and memory [56] \\
\hline Siglec & Neuroprotection; alleviates microglial toxicity $[57,58]$ \\
\hline GRO-a & Oligodendrocyte proliferation and migration [59] \\
\hline HB-EGF & Neuroprotection and function [60] \\
\hline Angiogenin & Neuroprotection [61] \\
\hline Robo4 & Neurogenesis [62] \\
\hline OSM & Neuroprotection and homeostasis of neural precursor cells [63] \\
\hline Neurturin & Neuroprotection and neurogenesis [64] \\
\hline Endothelin & Functional activity: neurotransmission [65] \\
\hline \multicolumn{2}{|l|}{ NBE elevated } \\
\hline Platelet factor 4 & Neurogenesis [66] \\
\hline Erythropoietin & Neuroprotection [67] \\
\hline Fractalkine & Homeostasis: neuron/glia crosstalk [68] \\
\hline TNF- $\beta$ & Neuronal plasticity, synaptic scaling, hippocampal neurogenesis [69] \\
\hline TIMP-2 & Inhibits neuronal proliferation and promotes the differentiation [70] \\
\hline Betacellulin & Neurogenesis $[71,72]$ \\
\hline GDF5 & Neurogenesis and neuroprotection $[73,74]$. \\
\hline Osteoactivin & Neuroprotection: expressed on microglia — phagocytosis of myelin debris [75] \\
\hline IGF-BP2 & Neuronal plasticity, learning, and memory as well as information processing $[76,77]$ \\
\hline uPA & Neuroprotection and repair $[78,79]$ \\
\hline AgRP & Functional activity $[80,81]$ \\
\hline
\end{tabular}

signaling milieu promotes the "young" determinants of tissue health, rejuvenating the brain (and in fact, all tissues and parameters that were studied up-todate [18]).

\section{Materials and methods}

Animals

All in vivo experiments and procedures were performed in accordance with the policies set by the Office of Laboratory Animal Care and under the approved protocols at the University of California, Berkeley, and the Buck Institute for Research on Aging. Young male C57BL/6 mice (2 months old) were purchased from Jackson Laboratory while aged mice (18 months old) were purchased from the National Institute of Aging
(NIA). The aged mice were allowed to acclimate at the same animal facility that housed young mice for several weeks prior to the studies. All mice were fed identical diets. All aged mice used in the OO, ONBE, Old + vehicle, and Old + ABT 263 cohorts were obtained from the NIA.

\section{Number of animals $(N)$}

A power analysis was performed in order to determine the sample sizes for the experiments presented as described previously [18].

Jugular vein cannulation surgery and blood exchange procedures

Note that all equipment used for these procedures were autoclave sterilized. A bead sterilizer was used upon 
repeated contact with multiple mice. Jugular vein cannulation and blood apheresis procedures were performed as previously published [18, 21]. Briefly, mice were given buprenorphine $(0.1 \mathrm{mg} / \mathrm{kg})$ and anesthetized with 1-3\% isoflurane in oxygen to full relaxation. Ophthalmic ointment was applied to each eye to prevent drying. Mice were shaven around their necks, rested in dorsal recumbency, and betadine surgical scrub was applied to their bare skin three times. An isopropanol wipe was used to remove the betadine after each betadine application. The mice were then placed on a sterile field. Once there was no reaction to toe pinch, a $1-1.5-\mathrm{cm}$ incision was made to the right of the midline and the right internal jugular vein was isolated. A 6-0 silk suture was used to ligate the cranial end of the vein. Gentle tension was applied to the ligated end of the vein, while another 6-0 suture was passed underneath the vein and loosely knotted. A 25-gauge needle with its beveled end bent outward to $90^{\circ}$ was used to perform the venotomy. The 1-Fr end of a pre-heparinized 1-3Fr catheter (Instech Labs, C10PU-MJV1403) was promptly inserted into the jugular vein and the caudal ligature was tightened to hold the catheter in place. Once patency was confirmed, the catheter was plugged, and an additional cranial ligature is made to latch the catheter in place. Mice were then rested in left lateral decubitus to thread the catheter between their scapulae. To accomplish this, blunt forceps were used to create space underneath the skin, passing the incision site to the scapulae. A 16-guage needle was positioned between the scapulae and inserted underneath the skin at the level of the incision site. The 3-Fr end of the catheter was passed through the 16-guage needle. Reflex 7 wound clips were used to close the incision site, and the catheter protruding the skin was secured with a drop of Dermabond. The mice were taken off anesthesia, given meloxicam subcutaneously $(5 \mathrm{mg} / \mathrm{kg})$ for 7 days post-procedure, and allowed to recover in their caged. Antibiotic ointment with lidocaine was applied to the closed site. The mice were taken off anesthesia and dosed with subcutaneous meloxicam ( $5 \mathrm{mg} / \mathrm{kg}$ s.q.) for 7 days postprocedure.

Blood from young or aged donor mice was obtained by a terminal cardiac puncture and anti-coagulated with 3 units of heparin. Blood samples were centrifuged spun at $500 \mathrm{~g}$ for $5 \mathrm{~min}$. The platelet-rich plasma fractions were carefully removed; blood cell pellets were resuspended in normal saline and then spun down once more at $500 \mathrm{~g}$ for an additional $5 \mathrm{~min}$. The saline layer was removed, and blood cell pellets were then resuspended in an equal volume of 5\% MSA in normal saline, $0.9 \%$ sodium chloride. The replacement albumin is $>95 \%$ pure by manufacturer's analysis (https://mol-innov. com/products/albumin-mouse-plasma/). These blood

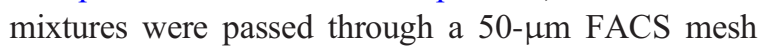
cap tube in order to de-clump cells and filter out any clots. Extracorporeal blood exchanges were performed between pairs of young mice, pairs of old mice, and young mice or old mice and a tube containing synchronic blood cells in 5\% MSA several hours following the surgeries. These designer blood solutions were prepared immediately prior to performing blood exchanges.

Blood exchanges were performed $24 \mathrm{~h}$ after cannulation surgeries to allow for adequate recovery. The mice were anesthetized once more with $1-3 \%$ isoflurane in oxygen and given ophthalmic ointment while resting in ventral recumbency. Catheters were assessed for patency and flushed with 3 units of heparin saline. A total of $150 \mu \mathrm{L}$ of blood was exchanged between the mouse and a tube of our designer blood solution 15 times for the $50 \%$ replacement of blood plasma with saline + albumin fluid, or for $50 \%$ synchronic young or old blood exchanges, as in [21]. The exchange process lasts approximately 30-40 min. Once completed, the catheters were plugged, the mice were taken off anesthesia, and they were allowed to recover.

\section{ABT-263 treatment}

For drug treatments, 22- to 24-month-old male C57BL/ 6 mice from the National Institute on Aging (Bethesda, MD, USA) were treated with vehicle or ABT 263 (APExBIO, USA) diluted in $10 \%$ ethanol, $30 \%$ polyethylene glycol 400, and 60\% Phosal 50 PG (Lipoid, Germany). ABT 263 was administered by oral gavage at $50 \mathrm{mg}$ per $\mathrm{kg}$ body weight per day $(\mathrm{mg} / \mathrm{kg} /$ day) for 7 days per cycle for two cycles with a 2 -week interval between the cycles.

\section{Cardiotoxin muscle injury}

Mice were injured by intramuscular injections of CTX (Sigma, $10 \mathrm{~mL}$ per muscle at $0.1 \mathrm{mg} / \mathrm{mL}$ ) into the tibialis anterior (TA) and gastrocnemius (GA), as previously published [1, 18, 21, 29]. 
Tissue isolation

Mice were sacrificed per the guidelines of UC Berkeley's and Buck Institute's OLAC administration. Blood was collected by terminal cardiac puncture and was allowed to clot completely at room temperature for at least $30 \mathrm{~min}$. Clotted blood samples were centrifuged at a speed of $5000 \mathrm{~g}$ for $5 \mathrm{~min}$ in order to obtain serum. Post-mortem isolation of brain was performed. Tissues were embedded in Tissue-Tek optimal cutting temperature (OCT, Sakura Finetek, The Netherlands) and snap frozen in isopentane cooled to $-70{ }^{\circ} \mathrm{C}$ with dry ice.

Tissue sectioning and brain mapping

OCT-embedded brains were sectioned with a cryostat. Coronal sections at $25 \mu \mathrm{m}$ thickness were attached to gold-supplemented positively charged glass coverslip slides. The cryostat was used to locate the midbrain, thalamus, and hypothalamus regions as stated above. These regions of the brain were located approximately 4.5-4.8 $\mathrm{mm}$ from the most posterior edge of the cerebellum. Subsequent tissue sections were collected for another $1 \mathrm{~mm}$ passing this mark.

\section{Senescence-associated $\beta$-galactosidase staining}

Senescence-associated $\beta$-galactosidase (SA- $\beta$-gal) staining was performed with a commercial Senescence $\beta$-Galactosidase Staining Kit (9860S, Cell Signaling Technology) according to the manufacturer's protocol. Briefly, frozen old mouse brain sections were fixed in the fixative solution (provided in the kit) for $15 \mathrm{~min}$ at room temperature. After washing twice with PBS, the sections were stained with the $\beta$-galactosidase staining solution at $37{ }^{\circ} \mathrm{C}$ overnight in a dry incubator (Thermolyne, type I42300 Incubator, USA). After staining, the images were captured using an Axio Imager A1 microscope (Zeiss, Germany) at a magnification of $\times$ 200 . The percentage of senescent area was determined by dividing blue-stained SA- $\beta$-gal-positive areas by the total area of each section, using the ImageJ software.

Antibodies and labeling reagents

The following antibodies were used at $0.5-1 \mu \mathrm{g} / \mathrm{mL}$ :

- CD68: Abcam, Rabbit, ab125212, 1:500

- Ki67: Abcam, Rabbit, ab16667, 1:200
- Isotype-matched IgGs: Sigma-Aldrich, Rabbit, $1: 1000$

- Donkey anti-rabbit Alexa 546: Life Technologies, Invitrogen, Eugene, Oregon, A10040, lot \#1946340, $1: 2000$

- Hoechst dye was used to stain DNA: Hoechst 33342, Sigma-Aldrich (B2261), 1:1000

Immunofluorescence of brain samples

Mouse brain was serially sectioned into 25 - $\mu$ m-thick sections that were then fixed in $4 \%$ paraformaldehyde for $4 \mathrm{~min}$ at room temperature. Subsequently, these sections are then rinsed with $1 \times$ phosphate-buffered saline (PBS) several times (2-3 min per rinse) and then permeabilized with $0.1 \%$ Triton-X over ice for $5 \mathrm{~min}$. Samples were then rinsed and blocked with PBS and 1\% staining buffer 3 times (2-3 min per rinse). Brain samples were then treated with primary antibodies and left to incubate overnight at $4{ }^{\circ} \mathrm{C}$. During the following day, sections are then washed 3 times (2-3 min per rinse) with staining buffer and then coated with secondary antibodies as described and incubated for $2 \mathrm{~h}$. Samples were then washed 3 times with staining buffer (2-3 min per rinse); then, 2 droplets of Fluoromount (Sigma F4680) mounting media were added and coverslips were then placed on top of samples. All tissue sections for immunofluorescence studies were mounted on positively charged gold SuperFrost slides.

Behavioral assays

The whisker-dependent texture discrimination test was performed as previously described [27, 28], with the encoding, resting, and testing phase lasting 10, 5, and 5 min, respectively. The novel object recognition (NOR) test was also conducted as previously described [27-29] with the encoding, resting, and the testing phases set to $10 \mathrm{~min}, 2 \mathrm{~h}$, and $10 \mathrm{~min}$, respectively. Such modifications of encoding and testing duration are intended to accommodate the slow movement of aged mice. Behavioral analyses were performed with the analyst blinded to the identity and the conditions (age, type of treatment) of the mice.

Principle component analysis

Principle component analysis was performed via singular value decomposition with the Python-scikit-learn 
decomposition package. The data was scaled using StandardScaler in the pre-processing method sklearn, and the features were normalized by mean protein expression. Python-Matplotlib was used to visualize the PCA-transformed data, and Python-Seaborn was used to generate the heat maps used to visualize the PC loading for each protein feature.

\section{Data quantification and statistics}

Neurogenesis was quantified by counting the number of $\mathrm{Ki}^{+} 7^{+} / \mathrm{H}^{+}$cells in $200 \mu \mathrm{m}$ of the SGZ from each mouse from multiple as previously described $[18,29]$. Neuroinflammation was scored by counting the number of $\mathrm{CD} 68^{+}$cells relative to the total number of nuclei counted per field of view. Mapping strategies have been described in Fig. 2. All analyses were performed on tissue sections that were imaged at $\times 20$ magnification. Non-paired, one-tailed, and two-tailed (as appropriate) Student's $t$ tests were performed in GraphPad Prism 8 for all tissue analysis data.

Supplementary Information The online version contains supplementary material available at https://doi.org/10.1007/s11357020-00297-8.

\begin{abstract}
Author contributions MM planned and conducted NBE and isochronic exchange procedures, planned neuroinflammation experiments, contributed to Fig. 1, provided Fig. 2 and Supplementary Figure 2, and co-wrote the manuscript. TM contributed to Fig. 2, provided Fig. 4, and participated in manuscript writing. CL provided Fig. 3. CMS and NW provided Fig. 5. CCC and YZ designed and performed the animal behavior study in Fig. 1 and Supplementary Figure 1. OJ performed ABT 263 administration for Fig. 4 and designed these experiments. MJC designed and directed the study, performed muscle injuries for Fig. 4, and cowrote the manuscript. IMC planned and directed the work, integrated and interpreted the data, and wrote the manuscript.
\end{abstract}

Funding This work was supported by the NIH RO1 NHLB 139605 and Open Philanthropy gift to IC and by the NIH T32 GM098218 fellowship and Jack Kent Cooke Graduate scholarship to CMS.Data availabilityAll relevant data was provided upon the submission of this manuscript.

\section{Compliance with ethical standards}

Conflict of interest The authors declare that they have no competing interests.
Open Access This article is licensed under a Creative Commons Attribution 4.0 International License, which permits use, sharing, adaptation, distribution and reproduction in any medium or format, as long as you give appropriate credit to the original author(s) and the source, provide a link to the Creative Commons licence, and indicate if changes were made. The images or other third party material in this article are included in the article's Creative Commons licence, unless indicated otherwise in a credit line to the material. If material is not included in the article's Creative Commons licence and your intended use is not permitted by statutory regulation or exceeds the permitted use, you will need to obtain permission directly from the copyright holder. To view a copy of this licence, visit http://creativecommons.org/licenses/by/4.0/.

\section{References}

1. Conboy IM, Conboy MJ, Wagers AJ, Girma ER, Weismann IL, Rando TA. Rejuvenation of aged progenitor cells by exposure to a young systemic environment. Nature. 2005;433:760-4. https://doi.org/10.1038/nature03260.

2. Conboy IM, Rando TA. Aging, stem cells and tissue regeneration: lessons from muscle. Cell Cycle. 2005;4:40710. https://doi.org/10.4161/cc.4.3.1518.

3. Conboy MJ, Conboy IM, Rando TA. Heterochronic parabiosis: historical perspective and methodological considerations for studies of aging and longevity. Aging Cell. 2013;12:525-30.

4. Conboy IM, Rando TA. Heterochronic parabiosis for the study of the effects of aging on stem cells and their niches. Cell Cycle. 2012;11:2260-7.

5. Conboy IM, Conboy MJ, Rebo J. Systemic problems: a perspective on stem cell aging and rejuvenation. Aging (Albany NY). 2015;7:754-65.

6. Bouchard J, Villeda SA. Aging and brain rejuvenation as systemic events. J Neurochem. 2015;132:5-19. https://doi. org/10.1111/jnc. 12969.

7. Patterson SL. Immune dysregulation and cognitive vulnerability in the aging brain: interactions of microglia, IL- $1 \beta$, BDNF and synaptic plasticity. Neuropharmacology. 2015;96:11-8. https://doi.org/10.1016/j. neuropharm.2014.12.020.

8. Fan X, Wheatley EG, Villeda SA. Mechanisms of hippocampal aging and the potential for rejuvenation. Annu Rev Neurosci. 2017;40:251-72. https://doi.org/10.1146 /annurev-neuro-072116-031357.

9. Villeda SA, Luo J, Mosher KI, Zou B, Britschgi M, Bieri $\mathrm{G}$, et al. The ageing systemic milieu negatively regulates neurogenesis and cognitive function. Nature. 2011;477: 90-6. https://doi.org/10.1038/nature10357.

10. Villeda SA, Plambeck KE, Middeldorp J, Castellano JM, Mosher KI, Luo J, et al. Young blood reverses age-related impairments in cognitive function and synaptic plasticity in mice. Nat Med. 2014;20:659-63. https://doi.org/10.1038 /nm.3569.

11. Carlson ME, Silva HS, Conboy IM. Aging of signal transduction pathways, and pathology. Exp Cell Res. 2008;314: 1951-61. 
12. Yousef H, Morgenthaler A, Schlesinger C, Bugaj L, Conboy IM, Schaffer DV. Age-associated increase in BMP signaling inhibits hippocampal neurogenesis. Stem Cells. 2015;33: 1577-88. https://doi.org/10.1002/stem.1943.

13. Yousef H, Conboy MJ, Morgenthaler A, Schlesinger C, Bugaj L, Paliwal P, et al. Systemic attenuation of the TGF$\beta$ pathway by a single drug simultaneously rejuvenates hippocampal neurogenesis and myogenesis in the same old mammal. Oncotarget. 2015;6:11959-78. https://doi. org/10.18632/oncotarget.3851.

14. Katsimpardi L, Litterman NK, Schein PA, Miller CM, Loffredo FS, Wojtkiewicz GR, Chen JW, Lee RT, Wagers AJ, Rubin LL (2014) Vascular and neurogenic rejuvenation of the aging mouse brain by young systemic factors. Science (80- ) 344:630-634. https://doi. org/10.1126/science.1251141.

15. Smith LK, He Y, Park JS, Bieri G, Snethlage CE, Lin K, et al. $\beta 2$-microglobulin is a systemic pro-aging factor that impairs cognitive function and neurogenesis. Nat Med. 2015;21:932-7. https://doi.org/10.1038/nm.3898.

16. Castellano JM, Mosher KI, Abbey RJ, McBride AA, James ML, Berdnik D, et al. Human umbilical cord plasma proteins revitalize hippocampal function in aged mice. Nature. 2017;544:488-92. https://doi.org/10.1038/nature22067.

17. Yousef H, Czupalla CJ, Lee D, Chen MB, Burke AN, Zera $\mathrm{KA}$, et al. Aged blood impairs hippocampal neural precursor activity and activates microglia via brain endothelial cell VCAM1. Nat Med. 2019;25:988-1000. https://doi. org/10.1038/s41591-019-0440-4.

18. Mehdipour M, Skinner C, Wong N, Lieb M, Liu C, Etienne $\mathrm{J}$, et al. Rejuvenation of three germ layers tissues by exchanging old blood plasma with saline-albumin. Aging (Albany NY). 2020;12:8790-819. https://doi. org/10.18632/aging.103418.

19. Brun CE, Rudnicki MA. GDF11 and the mythical fountain of youth. Cell Metab. 2015;22:54-6. https://doi. org/10.1016/j.cmet.2015.05.009.

20. Brack AS, Conboy MJ, Roy S, Lee M, Kuo CJ, Keller C, Rando TA (2007) Increased Wnt signaling during aging alters muscle stem cell fate and increases fibrosis. Science (80- ). https://doi.org/10.1126/science.1144090.

21. Rebo J, Mehdipour M, Gathwala R, Causey K, Liu Y, Conboy MJ, et al. A single heterochronic blood exchange reveals rapid inhibition of multiple tissues by old blood. Nat Commun. 2016;7. https://doi.org/10.1038/ncomms13363.

22. Rosenberg GA. Matrix metalloproteinases and their multiple roles in neurodegenerative diseases. Lancet Neurol. 2009;8:205-16.

23. Duits FH, Hernandez-Guillamon M, Montaner J, Goos JDC, Montañola A, Wattjes MP, et al. Matrix metalloproteinases in Alzheimer's disease and concurrent cerebral microbleeds. J Alzheimers Dis. 2015;48:711-20. https://doi.org/10.3233/JAD-143186.

24. Wang XX, Tan MS, Yu JT, Tan L. Matrix metalloproteinases and their multiple roles in Alzheimer's disease. Biomed Res Int. 2014;2014:908636-8. https://doi. org/10.1155/2014/908636.

25. Shytikov D, Balva O, Debonneuil E, Glukhovskiy P, Pishel I. Aged mice repeatedly injected with plasma from young mice: a survival study. Biores Open Access. 2014;3:22632. https://doi.org/10.1089/biores.2014.0043.
26. Sha SJ, Deutsch GK, Tian L, Richardson K, Coburn M, Gaudioso JL, et al. Safety, tolerability, and feasibility of young plasma infusion in the plasma for Alzheimer symptom amelioration study: a randomized clinical trial. JAMA Neurol. 2019;76:35-40. https://doi.org/10.1001 /jamaneurol.2018.3288.

27. Chen C-C, Lu J, Yang R, Ding JB, Zuo Y. Selective activation of parvalbumin interneurons prevents stressinduced synapse loss and perceptual defects. Mol Psychiatry. 2018;23:1614-25. https://doi.org/10.1038 /mp.2017.159.

28. Antunes M, Biala G. The novel object recognition memory: neurobiology, test procedure, and its modifications. Cogn Process. 2012;13:93-110. https://doi.org/10.1007 /s10339-011-0430-z.

29. Mehdipour M, Etienne J, Chen C-C, Gathwala R, Rehman $\mathrm{M}$, Kato C, et al. Rejuvenation of brain, liver and muscle by simultaneous pharmacological modulation of two signaling determinants, that change in opposite directions with age. Aging (Albany NY). 2019;11:5628-45. https://doi. org/10.18632/aging.102148.

30. Harada CN, Natelson Love MC, Triebel KL. Normal cognitive aging. Clin Geriatr Med. 2013;29:737-52. https://doi.org/10.1016/j.cger.2013.07.002.

31. van Praag H, Kempermann G, Gage FH. Running increases cell proliferation and neurogenesis in the adult mouse dentate gyrus. Nat Neurosci. 1999;2:266-70. https://doi.org/10.1038/6368.

32. Wu HP, Ioffe JC, Iverson MM, Boon JM, Dyck RH. Novel, whisker-dependent texture discrimination task for mice. Behav Brain Res. 2013;237:238-42. https://doi. org/10.1016/j.bbr.2012.09.044.

33. Hsu C-C, Serio A, Amdursky N, Besnard C, Stevens MM. Fabrication of hemin-doped serum albumin-based fibrous scaffolds for neural tissue engineering applications. ACS Appl Mater Interfaces. 2018;10:5305-17. https://doi. org/10.1021/acsami.7b18179.

34. Lueptow LM. Novel object recognition test for the investigation of learning and memory in mice. J Vis Exp. 2017;55718. https://doi.org/10.3791/55718.

35. Lian BSX, Yek AEH, Shuvas H, Abdul Rahman SF, Muniandy K, Mohana-Kumaran N. Synergistic antiproliferative effects of combination of ABT-263 and MCL-1 selective inhibitor A-1210477 on cervical cancer cell lines. BMC Res Notes. 2018;11:197. https://doi. org/10.1186/s13104-018-3302-0.

36. Wang H, Hong B, Li X, Deng K, Li H, Yan Lui VW, et al. JQ1 synergizes with the Bcl-2 inhibitor ABT-263 against MYCN-amplified small cell lung cancer. Oncotarget. 2017;8:86312-24. https://doi.org/10.18632 /oncotarget.21146.

37. Lin Q-H, Que F-C, Gu C-P, Zhong D-S, Zhou D, Kong Y, et al. ABT-263 induces $\mathrm{G}(1) / \mathrm{G}(0)$-phase arrest, apoptosis and autophagy in human esophageal cancer cells in vitro. Acta Pharmacol Sin. 2017;38:1632-41. https://doi. org/10.1038/aps.2017.78.

38. Lee Y-C, Wang L-J, Huang C-H, Shi Y-J, Chang L-S. ABT-263-induced MCL1 upregulation depends on autophagy-mediated 4EBP1 downregulation in human leukemia cells. Cancer Lett. 2018;432:191-204. https://doi. org/10.1016/j.canlet.2018.06.019. 
39. Pan J, Li D, Xu Y, Zhang J, Wang Y, Chen M, et al. Inhibition of Bcl-2/xl with ABT-263 selectively kills senescent type II pneumocytes and reverses persistent pulmonary fibrosis induced by ionizing radiation in mice. Int $\mathrm{J}$ Radiat Oncol Biol Phys. 2017;99:353-61. https://doi. org/10.1016/j.ijrobp.2017.02.216.

40. Sharma AK, Roberts RL, Benson RD Jr, Pierce JL, Yu K, Hamrick MW, et al. The senolytic drug Navitoclax (ABT263) causes trabecular bone loss and impaired osteoprogenitor function in aged mice. Front cell Dev Biol. 2020;8:354. https://doi.org/10.3389/fcell.2020.00354.

41. Chang J, Wang Y, Shao L, Laberge RM, Demaria M, Campisi J, et al. Clearance of senescent cells by ABT263 rejuvenates aged hematopoietic stem cells in mice. Nat Med. 2016;22:78-83. https://doi.org/10.1038/nm.4010.

42. Kirkland JL, Tchkonia T. Senolytic drugs: from discovery to translation. J Intern Med n/a. 2020;288:518-36. https://doi.org/10.1111/joim.13141.

43. Yu X, Dobrikov M, Keir ST, Gromeier M, Pastan IH, Reisfeld R, et al. Synergistic antitumor effects of 9.2.27PE38KDEL and ABT-737 in primary and metastatic brain tumors. PLoS One. 2019;14:e0210608.

44. Yamaguchi R, Perkins G (2012) Finding a panacea among combination cancer therapies. Cancer Res 72:18 LP - 23. https://doi.org/10.1158/0008-5472.CAN-11-3091.

45. Senatorov VV, Friedman AR, Milikovsky DZ, Ofer J, Saar-Ashkenazy R, Charbash A, et al. Blood-brain barrier dysfunction in aging induces hyperactivation of TGF $\beta$ signaling and chronic yet reversible neural dysfunction. Sci Transl Med. 2019;11:eaaw8283. https://doi. org/10.1126/scitranslmed.aaw8283.

46. Heinemann U, Kaufer D, Friedman A. Blood-brain barrier dysfunction, TGF $\beta$ signaling, and astrocyte dysfunction in epilepsy. Glia. 2012;60:1251-7. https://doi.org/10.1002 /glia.22311.

47. Banks WA, Farr SA, Morley JE. Permeability of the bloodbrain barrier to albumin and insulin in the young and aged SAMP8 mouse. Journals Gerontol Ser A. 2000;55:B6016. https://doi.org/10.1093/gerona/55.12.B601.

48. Balusu S, Van Wonterghem E, De Rycke R, Raemdonck K, Stremersch S, Gevaert K, et al. Identification of a novel mechanism of blood-brain communication during peripheral inflammation via choroid plexus-derived extracellular vesicles. EMBO Mol Med. 2016;8:1162-83. https://doi. org/10.15252/emmm.201606271.

49. Cattaneo A, Cattane N, Galluzzi S, Provasi S, Lopizzo N, Festari C, et al. Association of brain amyloidosis with proinflammatory gut bacterial taxa and peripheral inflammation markers in cognitively impaired elderly. Neurobiol Aging. 2017;49:60-8. https://doi.org/10.1016/j. neurobiolaging.2016.08.019.

50. Bettcher BM, Neuhaus J, Wynn MJ, Elahi FM, Casaletto $\mathrm{KB}$, Saloner R, et al. Increases in a pro-inflammatory chemokine, MCP-1, are related to decreases in memory over time. Front Aging Neurosci. 2019;11:25. https://doi. org/10.3389/fnagi.2019.00025.

51. Yang AC, Stevens MY, Chen MB, Lee DP, Stähli D, Gate $\mathrm{D}$, et al. Physiological blood-brain transport is impaired with age by a shift in transcytosis. Nature. 2020;583:42530. https://doi.org/10.1038/s41586-020-2453-z.
52. Walton CC, Begelman D, Nguyen W, Andersen JK. Senescence as an amyloid cascade: the amyloid senescence hypothesis. Front Cell Neurosci. 2020;14:129. https://doi. org/10.3389/fncel.2020.00129.

53. Miranda M, Morici JF, Zanoni MB, Bekinschtein P. Brainderived neurotrophic factor: a key molecule for memory in the healthy and the pathological brain. Front Cell Neurosci. 2019;13:363. https://doi.org/10.3389/fncel.2019.00363.

54. Hong H-S, Maezawa I, Petrlova J, Zhao X-Y, Voss JC, Jin L-W. Tomoregulin (TMEFF2) binds Alzheimer's disease amyloid- $\beta(\mathrm{A} \beta)$ oligomer and $\mathrm{A} \beta \mathrm{PP}$ and protects neurons from $A \beta$-induced toxicity. J Alzheimers Dis. 2015;48: 731-43. https://doi.org/10.3233/JAD-150318.

55. Ruiz de Almodovar C, Lambrechts D, Mazzone M, Carmeliet P. Role and therapeutic potential of VEGF in the nervous system. Physiol Rev. 2009;89:607-48. https://doi.org/10.1152/physrev.00031.2008.

56. Beroun A, Mitra S, Michaluk P, Pijet B, Stefaniuk M, Kaczmarek L. MMPs in learning and memory and neuropsychiatric disorders. Cell Mol Life Sci. 2019;76:3207-28. https://doi.org/10.1007/s00018-019-03180-8.

57. Linnartz B, Wang Y, Neumann H. Microglial immunoreceptor tyrosine-based activation and inhibition motif signaling in neuroinflammation. Int J Alzheimers Dis. 2010;2010:587463-7. https://doi.org/10.4061/2010 1587463.

58. Siddiqui SS, Matar R, Merheb M, Hodeify R, Vazhappilly $\mathrm{CG}$, Marton J, et al. Siglecs in brain function and neurological disorders. Cells. 2019;8:1125. https://doi. org/10.3390/cells8101125.

59. Filipovic R, Jakovcevski I, Zecevic N. GRO- $\alpha$ and CXCR2 in the human fetal brain and multiple sclerosis lesions. Dev Neurosci. 2003;25:279-90. https://doi. org/10.1159/000072275.

60. Oyagi A, Hara H. Essential roles of heparin-binding epidermal growth factor-like growth factor in the brain. CNS Neurosci Ther. 2012;18:803-10. https://doi.org/10.1111 /j.1755-5949.2012.00371.x.

61. Steidinger TU, Standaert DG, Yacoubian TA. A neuroprotective role for angiogenin in models of Parkinson's disease. J Neurochem. 2011;116:334-41. https://doi. org/10.1111/j.1471-4159.2010.07112.x.

62. Zheng W, Geng A, Li P, Wang Y, Yuan X. Robo4 regulates the radial migration of newborn neurons in developing neocortex. Cereb Cortex. 2012;22:2587-601. https://doi. org/10.1093/cercor/bhr330.

63. Houben E, Hellings N, Broux B. Oncostatin M, an underestimated player in the central nervous system. Front Immunol. 2019;10:1165. https://doi.org/10.3389 /fimmu.2019.01165.

64. Widenfalk J, Nosrat C, Tomac A, Westphal H, Hoffer B, Olson L (1997) Neurturin and glial cell line-derived neurotrophic factor receptor- $\beta$ (GDNFR- $\beta$ ), novel proteins related to GDNF and GDNFR- $\alpha$ with specific cellular patterns of expression suggesting roles in the developing and adult nervous system and in peripheral organs. $J$ Neurosci 17:8506 LP - 8519 . https://doi.org/10.1523 /JNEUROSCI.17-21-08506.1997.

65. Koyama Y. Endothelin systems in the brain: involvement in pathophysiological responses of damaged nerve tissues. 
Biomol Concepts. 2013;4:335-47. https://doi.org/10.1515 /bmc-2013-0004.

66. Leiter O, Seidemann S, Overall RW, Ramasz B, Rund N, Schallenberg S, et al. Exercise-induced activated platelets increase adult hippocampal precursor proliferation and promote neuronal differentiation. Stem Cell Reports. 2019;12: 667-79. https://doi.org/10.1016/j.stemcr.2019.02.009.

67. El-Kordi A, Radyushkin K, Ehrenreich H. Erythropoietin improves operant conditioning and stability of cognitive performance in mice. BMC Biol. 2009;7:37. https://doi. org/10.1186/1741-7007-7-37.

68. Sheridan GK, Murphy KJ. Neuron-glia crosstalk in health and disease: fractalkine and $\mathrm{CX}_{3} \mathrm{CR} 1$ take centre stage. Open Biol. 2013;3:130181. https://doi.org/10.1098 /rsob.130181.

69. McCoy MK, Tansey MG. TNF signaling inhibition in the CNS: implications for normal brain function and neurodegenerative disease. J Neuroinflammation. 2008;5:45. https://doi.org/10.1186/1742-2094-5-45.

70. Pérez-Martínez L, Jaworski DM (2005) Tissue inhibitor of metalloproteinase-2 promotes neuronal differentiation by acting as an anti-mitogenic signal. J Neurosci 25:4917 LP 4929. https://doi.org/10.1523/JNEUROSCI.5066-04.2005.

71. Gómez-Gaviro MV, Scott CE, Sesay AK, Matheu A, Booth S, Galichet C, et al. Betacellulin promotes cell proliferation in the neural stem cell niche and stimulates neurogenesis. Proc Natl Acad Sci U S A. 2012;109:131722. https://doi.org/10.1073/pnas.1016199109.

72. Novak U, Walker F, Kaye A. Expression of EGFR-family proteins in the brain: role in development, health and disease. J Clin Neurosci. 2001;8:106-11. https://doi. org/10.1054/jocn.2000.0799.

73. Wu H, Li J, Xu D, Zhang Q, Cui T. Growth differentiation factor 5 improves neurogenesis and functional recovery in adult mouse hippocampus following traumatic brain injury. Front Neurol. 2018;9:592. https://doi.org/10.3389 /fneur.2018.00592.

74. Sullivan AM, O'Keeffe GW. The role of growth/ differentiation factor 5 (GDF5) in the induction and survival of midbrain dopaminergic neurones: relevance to Parkinson's disease treatment. J Anat. 2005;207:219-26. https://doi.org/10.1111/j.1469-7580.2005.00447.x.

75. Satoh J-I, Kino Y, Yanaizu M, Ishida T, Saito Y. Microglia express GPNMB in the brains of Alzheimer's disease and Nasu-Hakola disease. Intractable rare Dis Res. 2019;8: 120-8. https://doi.org/10.5582/irdr.2019.01049.

76. Khan S. IGFBP-2 signaling in the brain: from brain development to higher order brain functions. Front Endocrinol (Lausanne). 2019;10:822. https://doi.org/10.3389 /fendo.2019.00822.

77. Lewitt MS, Boyd GW. The role of insulin-like growth factors and insulin-like growth factor-binding proteins in the nervous system. Biochem insights. 2019;12: 1178626419842176-6. https://doi.org/10.1177 /1178626419842176.

78. Yepes M. Urokinase-type plasminogen activator is a modulator of synaptic plasticity in the central nervous system: implications for neurorepair in the ischemic brain. Neural Regen Res. 2020;15:620-4. https://doi.org/10.4103/16735374.266904.
79. Merino P, Yepes M (2018) Urokinase-type plasminogen activator induces neurorepair in the ischemic brain. $\mathrm{J}$ Neurol Exp Neurosci 4:24-29. https://doi.org/10.17756 /jnen.2018-039

80. Cansell C, Denis R, Joly-Amado A, Castel J, Luquet S. Arcuate AgRP neurons and the regulation of energy balance. Front Endocrinol (Lausanne). 2012;3:169. https://doi.org/10.3389/fendo.2012.00169.

81. Mikhrina AL, Romanova IV. The role of AGRP in regulating dopaminergic neurons in the brain. Neurosci Behav Physiol. 2015;45:536-41. https://doi.org/10.1007/s11055015-0107-7.

82. Boada M, Ortiz P, Anaya F, Hernández I, Muñoz J, Núñez L, et al. Amyloid-targeted therapeutics in Alzheimer's disease: use of human albumin in plasma exchange as a novel approach for $A \beta$ mobilization. Drug News Perspect. 2009;22:325-39.

83. Loeffler DA. AMBAR, an encouraging Alzheimer's trial that raises questions. Front Neurol. 2020;11:459. https://doi.org/10.3389/fneur.2020.00459.

84. Boada M, Anaya F, Ortiz P, Olazarán J, Shua-Haim JR, Obisesan TO, et al. Efficacy and safety of plasma exchange with $5 \%$ albumin to modify cerebrospinal fluid and plasma amyloid- $\beta$ concentrations and cognition outcomes in Alzheimer's disease patients: a multicenter, randomized, controlled clinical trial. J Alzheimers Dis. 2017;56:129-43. https://doi.org/10.3233/JAD-160565.

85. Cuberas-Borrós G, Roca I, Boada M, Tárraga L, Hernández I, Buendia M, et al. Longitudinal neuroimaging analysis in mild-moderate Alzheimer's disease patients treated with plasma exchange with $5 \%$ human albumin. J Alzheimers Dis. 2018;61:321-32. https://doi.org/10.3233 /JAD-170693.

86. Boada M, López O, Núñez L, Szczepiorkowski ZM, Torres M, Grifols C, et al. Plasma exchange for Alzheimer's disease Management by Albumin Replacement (AMBAR) trial: study design and progress. Alzheimer's Dement (New York, N Y). 2019;5:61-9. https://doi. org/10.1016/j.trci.2019.01.001.

87. Zhu Y, Tchkonia T, Fuhrmann-Stroissnigg H, Dai HM, Ling YY, Stout MB, et al. Identification of a novel senolytic agent, navitoclax, targeting the Bcl-2 family of anti-apoptotic factors. Aging Cell. 2016;15:428-35. https://doi.org/10.1111/acel.12445.

88. Wang L-J, Liou L-R, Shi Y-J, Chiou J-T, Lee Y-C, Huang $\mathrm{C}-\mathrm{H}$, et al. Albendazole-induced SIRT3 upregulation protects human leukemia K562 cells from the cytotoxicity of MCL1 suppression. Int J Mol Sci. 2020;21:3907. https://doi.org/10.3390/ijms21113907.

89. Ohgino K, Terai H, Yasuda H, Nukaga S, Hamamoto J, Tani T, et al. Intracellular levels of reactive oxygen species correlate with ABT-263 sensitivity in non-small cell lung cancer cells. Cancer Sci n/a. 2020;111:3793-801. https://doi.org/10.1111/cas.14569.

90. Mukherjee N, Skees J, Todd KJ, West DA, Lambert KA, Robinson WA, et al. MCL1 inhibitors S63845/MIK665 plus Navitoclax synergistically kill difficult-to-treat melanoma cells. Cell Death Dis. 2020;11:443. https://doi. org/10.1038/s41419-020-2646-2.

91. Morimoto Y, Takada K, Takeuchi O, Watanabe K, Hirohara M, Hamamoto T, et al. Bcl-2/Bcl-xL inhibitor 
navitoclax increases the antitumor effect of Chk1 inhibitor prexasertib by inducing apoptosis in pancreatic cancer cells via inhibition of Bcl-xL but not Bcl-2. Mol Cell Biochem. 2020;472:187-98. https://doi.org/10.1007/s11010-02003796-6.

92. Tagscherer KE, Fassl A, Campos B, Farhadi M, Kraemer A, Böck BC, et al. Apoptosis-based treatment of glioblastomas with ABT-737, a novel small molecule inhibitor of Bcl-2 family proteins. Oncogene. 2008;27:6646-56. https://doi.org/10.1038/onc.2008.259.

93. Vogler M, Dickens D, Dyer MJS, Owen A, Pirmohamed M, Cohen GM. The B-cell lymphoma 2 (BCL2)-inhibitors, ABT-737 and ABT-263, are substrates for P-glycoprotein. Biochem Biophys Res Commun. 2011;408:344-9. https://doi.org/10.1016/j.bbrc.2011.04.043.

94. Marschallinger J, Schäffner I, Klein B, Gelfert R, Rivera FJ, Illes S, et al. Structural and functional rejuvenation of the aged brain by an approved anti-asthmatic drug. Nat Commun. 2015;6:8466. https://doi.org/10.1038 /ncomms9466.

95. Krukowski K, Chou A, Feng X, Tiret B, Paladini M-S, Riparip L-K, et al. Traumatic brain injury in aged mice induces chronic microglia activation, synapse loss, and complement-dependent memory deficits. Int J Mol Sci. 2018;19:3753. https://doi.org/10.3390/ijms19123753.

96. Chou A, Krukowski K, Morganti JM, Riparip L-K, Rosi S. Persistent infiltration and impaired response of peripherally-derived monocytes after traumatic brain injury in the aged brain. Int J Mol Sci. 2018;19:1616. https://doi. org/10.3390/ijms19061616.

97. Morganti JM, Jopson TD, Liu S, Riparip L-K, Guandique CK, Gupta N, et al. CCR2 antagonism alters brain macrophage polarization and ameliorates cognitive dysfunction induced by traumatic brain injury. J Neurosci. 2015;35: 748-60. https://doi.org/10.1523/JNEUROSCI.240514.2015.

98. Hsieh CL, Niemi EC, Wang SH, Lee CC, Bingham D, Zhang J, et al. CCR2 deficiency impairs macrophage infiltration and improves cognitive function after traumatic brain injury. J Neurotrauma. 2014;31:1677-88. https://doi.org/10.1089/neu.2013.3252.
99. Desale SE, Chinnathambi S. Role of dietary fatty acids in microglial polarization in Alzheimer's disease. J Neuroinflammation. 2020;17:93. https://doi.org/10.1186 /s12974-020-01742-3.

100. Leyns CEG, Holtzman DM. Glial contributions to neurodegeneration in tauopathies. Mol Neurodegener. 2017;12: 50. https://doi.org/10.1186/s13024-017-0192-x.

101. Scott G, Hellyer PJ, Ramlackhansingh AF, Brooks DJ, Matthews PM, Sharp DJ. Thalamic inflammation after brain trauma is associated with thalamo-cortical white matter damage. J Neuroinflammation. 2015;12:224. https://doi.org/10.1186/s12974-015-0445-y.

102. Norden DM, Godbout JP. Review: microglia of the aged brain: primed to be activated and resistant to regulation. Neuropathol Appl Neurobiol. 2013;39:19-34. https://doi. org/10.1111/j.1365-2990.2012.01306.x.

103. Kanaan NM, Kordower JH, Collier TJ. Age-related changes in glial cells of dopamine midbrain subregions in rhesus monkeys. Neurobiol Aging. 2010;31:937-52. https://doi. org/10.1016/j.neurobiolaging.2008.07.006.

104. Cagnin A, Brooks DJ, Kennedy AM, Gunn RN, Myers R, Turkheimer FE, et al. In-vivo measurement of activated microglia in dementia. Lancet. 2001;358:461-7. https://doi.org/10.1016/S0140-6736(01)05625-2.

105. Zhang G, Li J, Purkayastha S, Tang Y, Zhang H, Yin Y, et al. Hypothalamic programming of systemic ageing involving IKK- $\beta$, NF-kB and GnRH. Nature. 2013;497: 211-6. https://doi.org/10.1038/nature12143.

106. Yirmiya R, Goshen I. Immune modulation of learning, memory, neural plasticity and neurogenesis. Brain Behav Immun. 2011;25:181-213. https://doi.org/10.1016/j. bbi.2010.10.015.

107. Takahashi Y, Yu Z, Sakai M, Tomita H. Linking activation of microglia and peripheral monocytic cells to the pathophysiology of psychiatric disorders. Front Cell Neurosci. 2016;10. https://doi.org/10.3389/fncel.2016.00144.

Publisher's note Springer Nature remains neutral with regard to jurisdictional claims in published maps and institutional affiliations. 